\title{
Analysis of Human Resource Management in Colleges and Universities
}

\author{
Wenjuan Zhou \\ Department of Economic Management,Sanmenxia Polytechnic, |Sanmenxia ,472000
}

Keyword: Colleges and universities; Management; Human resource

\begin{abstract}
Human resource management is a very important link in the management of colleges and universities. The level and innovation ability of human resource management is an important index to measure the overall work level of a school. The quality of human resources management determines the development potential and direction of this university to a certain extent. Therefore, colleges and universities should innovate continuously in the management of human resources, which is the only way to improve effectively the school's core competitiveness and promote school education and teachers' teaching level.

With the continuous development of Chinese social economy, university reform is imperative. After years of exploration and practice, college reform made many achievements in many ways. The reform of the internal personnel system in colleges and universities is an indispensable part of the reform of colleges and universities. The personnel system of colleges and universities has gradually established the concept of human resources, and the structure of teachers has been gradually optimized. As the cradle and the center of knowledge innovation of high - level talent, the level and development ability of human resource management is an important index to measure the actual running level of a university. In order to develop and innovate human resources management in colleges and universities, it should be made some breakthroughs in the ideas and methods. In the background of advocating quality education today, colleges and universities should take on their own social mission and strive to cultivate more high-level useful talents for the country with the sense of urgency and responsibility.

Strengthening the management, utilization and development of human resources in colleges and universities is an effective means to enhance the core competitiveness of colleges and universities. Colleges and universities must pay attention to the scientific management of human resources to stabilize and make good use of their own teachers and personnel. In the new era, how to build a teachers team with good quality, reasonable structure and competitive advantage is an important issue that every university has to face.
\end{abstract}

\section{The Scientific Connotation of Human Resource Management in Colleges and Universities}

Broadly speaking, human resources refer to the human resources that an organization has to use to make a product or provide services. In other words, an organization's human resources is that many individuals with a variety of different knowledge, skills and ability in the organization. They are engaged in a variety of scheduled work activities to achieve the objectives of the organization. Human resources management refers to the planned, organized and commanded control activities carried out in the aspects of the acquisition, development, maintenance and utilization of human resources. By coordinating the relationship between people and things in the social labor organization and the relationship between the people, it can fully develop human resources, tap the inherent potential of people to improve their enthusiasm of the activities and work efficiency and achieve organizational goals of the theory, methods, tools and technology.

The traditional university personnel management is a kind of business management to some extent and it only plays a role when the unit needs. Modern management concept and management system requires the human resources management of colleges and universities should guide the various types of personnel in colleges and universities with scientific principles and methods to make scientific and efficient planning, and coordinate various personnel relations, such as staff recruitment, training, rewards and punishments, assessment, retired work to achieve the high efficiency operation of human resources in colleges and universities. In a sense, human resources 
management in colleges and universities and enterprises have many similarities. Human resources management in colleges and universities achieve their purpose through people to do their best.

\section{The Necessity of Human Resource Management Innovation in Colleges and Universities}

In the background of economic globalization, management philosophy and management practices in various areas are greatly affected. Therefore, traditional management mode has become increasingly unable to adapt to the development of the times. As universities are at the forefront of the impact of new things, human resource management are the first to be affected. In the background of economic globalization, Chinese higher education has been integrated into the development of the world trend without going out of the country. Under the impact of internationalization of education, Chinese universities inevitably encounter competition with foreign counterparts in the source of students, the quality of education, academic and other aspects. On the other hand, economic globalization also makes the flow of talent more flexible and more and more people of insight pay attention to the problem of intellectual loss. Moreover, with the continuous improvement of the quality of university staff, they are more keen to engage in challenging and creative tasks, at the same time, they are more willing to unite professional quality and quality of life together. Finally, in the new historical period, national development for personnel training also put forward higher and more urgent requirements. In order to adapt to these changes, the innovation and development of human resource management in colleges and universities is imminent.

Colleges and universities have inexhaustible talents and research and development advantages. Colleges and universities should follow the trend of the times, reform their own system, change the traditional management concepts and meet the challenges.

\section{Human Resources in Colleges and Universities and Their Characteristics}

University is a special field and it is established based on personnel training and scientific research. The human resource management in colleges and universities has the particularity of matching with its status and mission. Human resource management should be based on the characteristics of colleges and universities and let the better completion of teaching objectives as the starting point and the foothold. At present, according to educational tasks and scientific research level, colleges and universities can be divided into three categories. One is a research-led university, which have a long history and good accumulation in scientific research and other aspects. The second category is institutions whose teaching and research is relatively balanced. The third category is the teaching-oriented university. No matter from which angle to divide, the difference between colleges and universities is that the proportion of research and teaching is different. And scientific research and academic are undoubtedly the center of the work of colleges and universities. The core of human resource management in colleges and universities is the management of academic level in colleges and universities, which runs through all the management work of colleges and universities. In the selection of talents in colleges and universities, we must first examine the academic development potential and the current academic level of the staff. In the distribution of personnel, academic direction and academic characteristics of the staff should be considered when make arrangements. In the staff training and further study, it should be proceed based on position and academic needs. All above require human resources management personnel in colleges and universities have a certain academic management experience.

The composition of the staff of the university is diverse, which including teachers, researchers and logistics personnel and so on. This requires that our management can not be a simple way. It should adopt different types of management based on different characteristics of the staff.

Comparing human resources management in colleges and universities with state organs and enterprises, the public welfare of human resources management in colleges and universities is more stronger, that is to say, the university does not use profit as the main purpose. The human resources of colleges and universities have strong freedom. The development of academic activities in 
colleges and universities is generally not related to economic interests, so independence and freedom are relatively high. After finish the teaching tasks, college teachers can arrange their own academic research work.

The value conversion of human resource management in colleges and universities takes a long period. First of all, the results of scientific research in colleges and universities are mostly theoretical results. It need to take a long time to verify whether the results can be applied to practice and generate economic benefits. Many scientific researches have a very strong forward-looking, so it can not be transformed into practical benefits in a short-term reality conditions. Second, college students training time is long. Undergraduates need to accept four years of theoretical education in order to reserve and accumulate knowledge. And it will take some time to apply what they learned into work.

\section{Problems of Human Resource Management in Chinese Universities}

After years of development, human resources management in China has made a big progress. However, there are still some problems. The author concluded the following main points.

Weak Concept. In theory, Chinese colleges and universities have experienced three stages, such as personnel management, human resource management and strategic human resource management. However, seen from the actual effect of view, many colleges and universities' human resources management is far from the point of strategic human resources management. Many of the human resources managers in colleges and universities lack understanding of the concept of advanced management and their innovation is not strong, so they are still in the traditional personnel management stage whether in the guiding ideology or work methods.

Incentive Mechanism Is not Perfect. College incentive mechanism is an effective means to mobilize the enthusiasm of the majority of workers. However, many colleges and universities ignore individual differences in the actual work. Managers neglect the majority of workers' characteristics when reward, such as age, personality and others. There is no difference in incentives as they did not understand the actual needs of different groups, so the incentive system lacks flexibility and systematic. Second, reward lacks timeliness. Many colleges and universities lack flexibility in the incentive measures. For example, they must reward people according to the scheduled date, which seriously affected the enthusiasm of the staff. Third, it lacks recognition of faculty. There are a variety of incentives, such as sense of achievement, challenges of work, work prospects and personal promotion opportunities and so on. Incentives can not only focus on one aspect. Employees can show more enthusiasm and initiative in their work only when their different needs are met. Fourth, incentive mechanism is not scientific. Each university should develop scientific and rigorous incentive standards based on their own characteristics and the actual situation.

Lack of Long-Term Planning. In the development of enterprise, it often encounter such a situation that technology and business are very mature lacking real talent. Some companies start their own class training in order to recruit the right staff. Nevertheless, the talent is still very easy to be recruited by other enterprises. The use and stability of talent is still a big problem for many enterprises. Colleges and universities are the gathering place of talent and the base to train talent. The social function of colleges and universities determines that colleges and universities have the obligation to cultivate high quality talents who can meet the needs of the times for country. The key point of personnel training is that the university itself has a group of high-quality teachers and administrative practitioners. In this regard, the current situation of colleges and universities in China is not optimistic. Chinese colleges and universities have not established a scientific and rational human resources management system.

Uneven Allocation of Resources. With the continuous advancement of Chinese higher education system reform, the scale of running a university in our country has been expanding year by year. Higher education has changed from elite education to national quality education. However, there is a serious imbalance between college teachers and students. In order to make up for the shortage of teachers, the colleges and universities have made great efforts to introduce young 
teachers. Besides, as economic development of East and West and development of urban is not balanced, the talent competition between universities and regions is intensifying. Therefore, geographical and school advantages become the main attraction for the flow of talent. These problems continue to be exposed and have a growing tendency, which plays a role in fueling the uneven distribution of resources.

\section{Measures of Strengthening the Human Resource Management in Colleges and Universities}

In recent years, the development of human resources management in colleges and universities has been widely concerned by the community. In order to meet the needs of the development of higher education in China, many institutions conduct exploratory reform for the human resources management system. Colleges and universities have done a lot of bold attempts and accumulated a lot of valuable experience in the title review, remuneration and the introduction of policies and so on. The author believes that to strengthen the university's human resources management should focus on the following aspects.

Strengthen the Human Subjectivity. Strengthen the human subjectivity is that everything should start from the reality and the needs of the majority of faculty. Make people as the the main body of concept, behavior and system. The purpose of strengthening the subjectivity of human beings is to make clear that people are the goals and the driving force of social development. Development must rely on talent and talent can promote development, which can help each other and they are indispensable. Talent is the foundation of the strong development of colleges and universities. Implementing the strategy of strengthening the field of talents is an important part of the scientific concept of development and talent strategy. The focus of human resources management in colleges and universities is to pay close attention to the construction of talent team. It is necessary to establish a comprehensive human resources management system and get rid of the institutional constraints of traditional system.

Establish and Improve the Incentive Mechanism. The establishment of incentive mechanism should be close to the actual situation of school. Combine the material reward and spiritual reward together. Material incentives includes wages, bonuses and various allowances. Besides, the amount of reward should match the job, social recognition and market demand and so on. The school should also concern about children' school and housing and other aspects of the majority of faculty to solve their worries, so that they threw himself into the work. Moreover, the school should prompt the faculty to coordinate their teaching behavior and the school's goals in the teaching process. Personal interests and the overall interests are closely linked to stimulate the enthusiasm of the staff.

Establish A Comprehensive View of Talent. The human resources management system should be flexible and efficient. And the necessary support and protection should be provided for the development of each employee. Meanwhile, let the staff in the system do their best to work together toward the same goal. The human resource division is the most important in all the resources of the university. In the evaluation of talent, we must establish a correct concept of talent and be good at exploring the advantages of different levels of talent to make full use of them. The most prominent advantage of a good university in the human resources management should be good at playing the role of Bole. The human resource division should treat different groups differently in the administration, student management, logistics management and other aspects to fully mobilize the work enthusiasm and creativity of all kinds of talent, give full play to personal expertise and strive to create a harmonious working atmosphere. In short, colleges and universities should establish a scientific concept of talent and strive to build a teacher team with noble moral, optimized structural and dynamic.

\section{Conclusion}

The human resource management in colleges and universities is a systematic and holistic work. Human resource management in colleges and universities is an important content of talent work in the new situation. Therefore, we must fully understand its importance, establish firmly the modern 
management philosophy and make full use of it in practical work. In the details of management, colleges and universities should have a comprehensive understanding of the wishes and aspirations of faculty, try to mobilize the initiative and creativity of employees and optimize the work development environment of the staff. The establishment of Chinese colleges and universities can move forward healthily and steadily only in this way.

\section{Reference}

[1] Z. H. Li. Research on Human Resource Management in Chinese Higher Education [D]. Northwest University, 2004.

[2] R. J. Yuan. Research on Human Resource Management in Colleges and Universities [D]. Zhengzhou University, 2003.

[3] P. Jiao. Research on Human Resource Management in Private Colleges [D]. Harbin Engineering University, 2007.

[4] Y. F. Guan and X. H. Chen. Research on Human Resource Management in Chinese Universities [J]. Modern University Education, 2009.

[5] D. D. Wang. Research on Human Resource Management in China [D]. Xi'an University of Architecture and Technology, 2009.

[6] W. Z. Liu. Research on Human Resource Management in Colleges and Universities Based on Customer Satisfaction [D]. Northwest University, 2010.

[7] Q. He. Research on Human Resource Management in Colleges and Universities Based on Quality Model [J]. Journal of Beijing Union University (Humanities and Social Sciences), 2007.

[8] K. W. Wang. A New Exploration of Human Resource Management in Colleges and Universities - A Review of Zheng chijian's Research on Human Resource Management in Colleges and Universities [J]. Journal of Hunan University of Science and Technology (Social Science Edition), 2007.

[9] Z. L. Xing. Research on Human Resource Management in Colleges and Universities Based on Internal Customer Satisfaction [J]. Journal of Liaoning Normal University (Social Science Edition), 2008, 05: 80-81.

[10] J. M. Zhu. Research on Human Resource Management in Colleges and Universities Based on Knowledge Management [J]. Science and Technology Information Development and Economy, 2008.

[11]M. Shuai. Research on Human Resource Management in Colleges and Universities Based on Knowledge Management [D]. Xiangtan University, 2010.

[12]L. G. Bao. Research on Human Resource Management in Guangxi Colleges and Universities [D]. Guangzhou University, 2008.

[13]B. F. Yan. Research on Human Resource Management in Local Colleges and Universities [J]. New West (Second Half), 2010.

[14] G. Z. Shi. Research on Human Resource Management in Colleges and Universities under the Scientific Concept of Development [J]. Education \& Occupation, 2009. 